\title{
Refractory Degradation in Glass tank Melters. A Survey of Testing Methods
}

\author{
M. Velez, J. Smith, R. E. Moore. University of Missouri-Rolla, \\ Department of Ceramic Engineering, Rolla, Missouri 65409-0330, USA
}

Abstract
The degradation of refractories used in the construction of glass melting
furnaces, whether caused by the action of molten glass, vaporized melt constituents,
products of fuel combustion, or by batch dusts and vapors, can normally only be
assessed after a campaign when the furnace is partially or completely disassembled.
Corrosion tests to predict degradation usually employs small specimens exposed
to accelerated working conditions which might not be simulative. The current
testing procedures are discussed in terms of advantages/disadvantages. Three
different tests seem to be needed to simulate the critical processes occurring in
glass tank melters: flux-line corrosion, throat corrosion and crown corrosion. A
pilot-size laboratory testing facility is being built for simulating corrosion attack
under different conditions.

\section{INTRODUTION}

The major objective in glass tank melters is to optimize the entire process by reducing the maximum temperature of melting, improving refractory performance and/or improving melter fuel efficiency. The required characteristics of refractories used in melters are: thermal shock resistance, corrosion resistance, controlled expansion behavior, low thermal conductivity, and adequate creep resistance.

The corrosion of the refractories in the melter may be due to batch carryover (lime, soda, fluorides, lead oxide, borax, silica, other glass constituents), volatile fluxes (i.e., volatile alkali oxides penetrating pores, where solid, liquid, and gas coexist), and melt attack, mainly at the metal line. Erosion often follows the initial corrosion, washing away refractory grains after the original bond has dissolved. Corrosion test designs are usually based on operation and reaction temperatures, reaction rates, and the formation of coatings on the refractory surface.

Refractories for glass furnaces normally are limited to compositions based on $\mathrm{Al}_{2} \mathrm{O}_{3}, \mathrm{ZrO}_{2}$, and $\mathrm{SiO}_{2}$, with or without $\mathrm{Cr}_{2} \mathrm{O}_{3}$. Alumina-zirconia-silicate (AZS) refractories in contact with molten glass form a viscous silicate layer adjacent to the refractory thus restricting contact, and therefore, increasing corrosion resistance. When AZS blocks are used in superstructures, they are exposed to high temperature combustion products. At temperatures above $1475{ }^{\circ} \mathrm{C}$, the bond strength between the embedded $\mathrm{ZrO}_{2}$ crystals and the alumina is reduced, attributed to the variation in the thermal expansion characteristics of $\mathrm{Al}_{2} \mathrm{O}_{3}$ and $\mathrm{ZrO}_{2}$.

Superstructure and crown refractories are subjected to corrosive reactions with the vapor species of the batch components and batch carryover. In the melting of soda-lime glasses, the vapor species are primarily soda and sodium sulfates; for borosilicate glasses, Na-tetraborate and $\mathrm{B}_{2} \mathrm{O}_{3}$ predominate. Direct attack occurs by condensation of the hot face of the refractory. The chemical changes in this reaction zone result in mechanical stresses and flaking, peeling or spalling of the hot face. Vapor penetration into joints with subsequent condensation and corrosion lowers the mechanical integrity of the superstructure or crown.

This work intends to summarize the tests to date, discussing their particular advantages, and emphasizing the corrosion of refractories in the melter tank. Most future melters are predicted to be under oxy-fuel combustion [1,2], with limited use of checkerwork refractories.

\section{BIBLIOGRAPHY SEARCH}

\section{Corrosion resistance of refractories to molten slags}

Several methods have been used to evaluate the dissolution rate of refractories, including (1) before and after profile measurements [i.e., 3-7]; (2) measurement of the change in weight [i.e., 8-10]; (3) electrochemical approaches [i.e., 11,12]; and (4) continuous gravimetric monitoring [i.e., 13-15]. The current standard tests for refractories in contact with molten slags include: isothermal corrosion resistance of refractories to molten glass [16]; corrosion resistance of refractories to molten glass while a temperature gradient is maintained through the refractory [17]; cup slag test; drip slag test [18]; gradient slag test; rotary slag test; and the dip and spin test [19]. These laboratory corrosion tests compare corrosion characteristics, effectively measuring the chemical compatibility between glass and refractory.

Bruckner [3] considered the different factors influencing the corrosion of refractories by commercial glasses. Given assumptions such as pure diffusion, entirely electrochemical processes and a 
uniform microstructure of the refractory, there are three corrosion mechanisms, forced convection, density induced free convection, and surface tension driven convection. He concluded that the surface tension has perhaps the strongest influence on corrosion.

Dunk1 [20] studied the corrosion rates of various refractories in a container glass melt ( $\mathrm{Na}-\mathrm{Ca}$-silicate) and determined quantitatively the action of forced convection flow by means of a rotating cylinder at 1400 and $1500{ }^{\circ} \mathrm{C}$. The corrosion rates were determined by measuring the decrease in length of cylindrical samples as a function of time at various rotation rates. The different initial stages of corrosion with refractory materials and a Na-Casilicate and E-glass melts was also investigated [21-22]. The corrosion of refractories by glass melts under the influence of density-, interfacial-, and forced-convection currents showed a linear dependence on time for the static corrosion process with respect to theoretical estimates.

Commercial AZS materials contain zirconia crystals 30-40 wt. $\%$, interlocked with corundum, and minor interstitial glass. They perform well in contact with many glasses melted at $1500{ }^{\circ} \mathrm{C}$ or lower, but have been found to react readily with new developmental glasses, particularly rare earth alumino-silicates having much higher melting temperatures, resulting in erosion of crystalline particles which appears as stones in the glass. Some molten glasses with higher melting temperatures cause high rates of corrosive wear of the $30-40$ wt. $\% \mathrm{ZrO}_{2}$ refractories [23]. The alumino-silicate forms an undesirable surface layer on the refractory when cooled upon shutdown for repairs. When the tank is reheated, the surface layer in contact with molten glass undergoes exfoliation.

Pavlovskii [24] tested $\mathrm{SiO}_{2}, \mathrm{Al}_{2} \mathrm{O}_{3}$, and $\mathrm{ZrO}_{2}$ in contact with silicate glasses containing large amounts of $\mathrm{PbO}$ (66 wt. \%, glass I; 8.5 wt. \%, glass II). Static conditions were used with the specimens semi-immersed, during $24-72 \mathrm{~h}$ at $1300{ }^{\circ} \mathrm{C}$ for glass I, while for the more corrosive glass II, $6-12 \mathrm{~h}$ at $1000{ }^{\circ} \mathrm{C}$. Specimens were cut and examined by optical microscopy. Corrosion resistance increased in the sequence $\mathrm{SiO}_{2}<\mathrm{Al}_{2} \mathrm{O}_{3}<\mathrm{MgO}<\mathrm{ZrO}_{2}$. The corrosive contact involves lead diffusing into the tetragonal $\mathrm{ZrO}_{2}$, and subsequent $\mathrm{ZrO}_{2}$ destabilization.

Soviet-produced fused-cast refractory materials manufactured under reducing conditions during melting, have a tendency to form defects when they are in contact with glass, as a result of reactions with oxygen-containing impurities [25]. Alumina fused cast refractories formed bubbles after contact with the glass. Specimens were placed in a furnace on a refractory substrate, heated to the specified temperature $\left(1250^{\circ} \mathrm{C}\right)$, and held for $15 \mathrm{~min}$. Two glass rods (10-15 $\mathrm{mm}$ long, $9 \mathrm{~mm}$ diameter) were placed on each specimen and again held at the temperature for $15 \mathrm{~min}$. During the second dwell, drops of glass saturated with bubbles covered the surface of the specimen.

Thomas [26] evaluated corrosion data of bonded aluminachrome refractories (10 and 16 wt. $\% \mathrm{Cr}_{2} \mathrm{O}_{3}$ ) and observed that they yield high corrosion resistance to soda-lime glass. He concluded that these refractories could be used as bottom pavers, sidewalls, and back-up shapes for high thermal efficiency construction. He used the finger corrosion test, reporting the flux line corrosion versus temperature and time of exposure.

Aspholm [27] studied the corrosion behavior of AZS-30 $\mathrm{Cr}_{2} \mathrm{O}_{3}$ (a rebonded AZS grain refractory with 30 wt. $\% \mathrm{Cr}_{2} \mathrm{O}_{3}$ in the matrix and fused AZS as the coarse aggregate) in wool glass melts using ASTM C-621 as the test. The main objective was to compare the relative glass corrosion resistance of this rebonded fused AZS$\mathrm{Cr}_{2} \mathrm{O}_{3}$ refractory with a typical $\mathrm{Al}_{2} \mathrm{O}_{3}-30 \mathrm{Cr}_{2} \mathrm{O}_{3}$ composition. The results indicated that the rebonded composition performs better.

Wehrenberg [28] studied the behavior of new AZS chromic oxide refractories (15 wt. \% $\mathrm{Cr}_{2} \mathrm{O}_{3}$ ) which showed enhanced corrosion resistance to wool fiber glass as compared to pure AZS. Corrosion resistance data was obtained using the ASTM C-621 finger test, with a $1 \mathrm{~cm}^{2} \times 5 \mathrm{~cm}$ long specimen at $1450{ }^{\circ} \mathrm{C}$ and a test duration of $4 \mathrm{~d}$.

The glass composition contained typically $19 \% \mathrm{Na}_{2} \mathrm{O}$ and $7 \% \mathrm{~B}_{2} \mathrm{O}_{3}$.

These refractories are intended for sidewalls, pavers, overcoatings, ports, stacks, and regenerators.

Baucke [11] studied the formation of oxygen bubbles at the interface of untreated zirconia-silicate $(\mathrm{ZS})$ refractories in contact with glass melts. He observed that a redox reaction proceeds via a reaction layer below the ZS surface, and forms a galvanic cell with a growing thickness. The relation rate is controlled by solid state diffusion of charge-balancing alkali ions. The internal reduction could be altered by an external voltage. The reaction mechanism seemed only valid for alkali-ion containing melts with oxidizable ions (i.e., Na-halide melts).

\section{Vapor attack of crown and superstructure}

Two types of batch impingement tests are described in the literature [29]: (1) the rotating finger test where refractory samples are subjected to attack by direct flame and selected raw batch components (a very severe test, to demonstrate the destructive effect of a batch-laden flame impinging directly on the refractory superstructure or when the flame is directed too sharply on the batch blanket and deflects against the superstructure); and (2) the panel test where stationary refractory test blocks are subjected to direct batch and flame attack. The temperature could be cycled to simulate conditions of a port or regenerator target wall area.

A pencil-crucible vapor test has been demonstrated to yield selective attack from batch components adequately simulating the direct reaction of vapor and/or resulting condensates [30]. The method involves the use of a dense alumina crucible containing the reactant and a test refractory serving as the crucible cover. This test which simulates a superstructure, has been used with a range of refractories using the vapor from $\mathrm{Na}$ and $\mathrm{K}$-carbonate heated to $1371{ }^{\circ} \mathrm{C}$ for $24 \mathrm{~h}$ [31]. Results indicated the destructive effect of concentrated alkali vapors. Conventional silica bricks were observed to be severely corroded which resulted in substantial volume loss after $24 \mathrm{~h}$ at $1371{ }^{\circ} \mathrm{C}$ using $\mathrm{Na}_{2} \mathrm{CO}_{3}$ as the reactant. Zircon showed a high degree of wetting by the soda vapor, extensive reaction, and development of an interfacial layer of zirconia.

Bieler [32] tested five types of refractories (silica, mullite, zircon, bonded AZS, and fused-cast AZS) suspended over 7 molten salts: $\mathrm{Na}_{2} \mathrm{CO}_{3}$, Na-borate, $\mathrm{Na}_{2} \mathrm{SO}_{4}, \mathrm{Na}-\mathrm{Si}$-fluoride, $\mathrm{H}_{3} \mathrm{BO}_{3}, \mathrm{~Pb}$ monosilicate, and a Na-carbonate, $\mathrm{Pb}$-monosilicate mixture. Specimens were exposed for $24 \mathrm{~h}$ at $1371{ }^{\circ} \mathrm{C}$. Silica specimens were greatly attacked by all Na-containing salts. Bloating and minor to moderate surface reaction occurred in all the mullite and zircon specimens in the salt vapor tests.

Popov [33] studied the structure and phase composition of a baddeleyite-corundum refractory in a high operating temperature (1580-1590 ${ }^{\circ} \mathrm{C}$ ) glass furnace. The observed corrosion of the 
elements of the upper structure was caused by chemical interaction of the refractory with the volatile components of the molten silicate, the dust of the charge, and the fuel combustion products contained in the high-temperature gas flow. Failure was also accelerated by sharp temperature differentials on the surface of the refractory related to the change in flame direction in the furnace (up to $60-100^{\circ} \mathrm{C}$ every $30 \mathrm{~min}$ ). In some cases, extensive cordierite crystallization was observed.

Routschka [34] studied (1) the behavior of AZS refractory bricks in contact with molten $\mathrm{Na}_{2} \mathrm{SO}_{4}, \mathrm{NaCl}$, and alkali phosphates at temperatures between 800 and $1200{ }^{\circ} \mathrm{C}$; and (2) the behavior of low-alumina fire-clay, andalusite, mullite-bonded corundum and zircon bricks exposed to alkaline vapor of a mixture of $\mathrm{Na}_{2} \mathrm{SO}_{4}+$ $\mathrm{NaCl}$ at $1100{ }^{\circ} \mathrm{C}$ up to $28 \mathrm{~d}$ (isothermal corrosion test). The gas phase which formed interacted with the refractory specimens placed in the box.

The proposed advantages of the test are (a) simultaneous, long-time testing of several types of refractories of different chemical, mineralogical and physical properties under high concentration of alkali vapors; (b) evaluation of a large number of specimens of each refractory composition for statistical evaluation; and (c) examination of changes in chemical and mineralogical compositions as well as physical properties determined after testing without additional heat treatment.

Boillet [35] reported results from analysis of refractory specimens placed in an oxy-fuel fired glass furnace. The tests were conducted in a soda-lime industrial glass furnace with a $100 \%$ oxy-firing combustion process. Silica and mullite refractory specimens were located in 3 regions of the furnace: (1) close to the burner block and installed at the back wall, (2) at the left side of the furnace throat, and (3) at the right side of the furnace throat. Samples were taken after 15 and 30 days of exposure. Characterization was carried out using scanning electron microscopy (SEM) with microanalysis, X-ray diffraction (XRD), Hg-porosimetry, and Xray fluorescence (XRF). The following mechanism was proposed for the corrosion of silica: (1) alkaline vapors (mainly $\mathrm{Na}_{2} \mathrm{O}$ from the glass melt) diffuse to the interior of the refractory and react with silica: followed by (2) phase transformation of cristobalite to tridimite and consequent corrosion of the tridimite by the $\mathrm{Na}_{2} \mathrm{SiO}_{3}$,

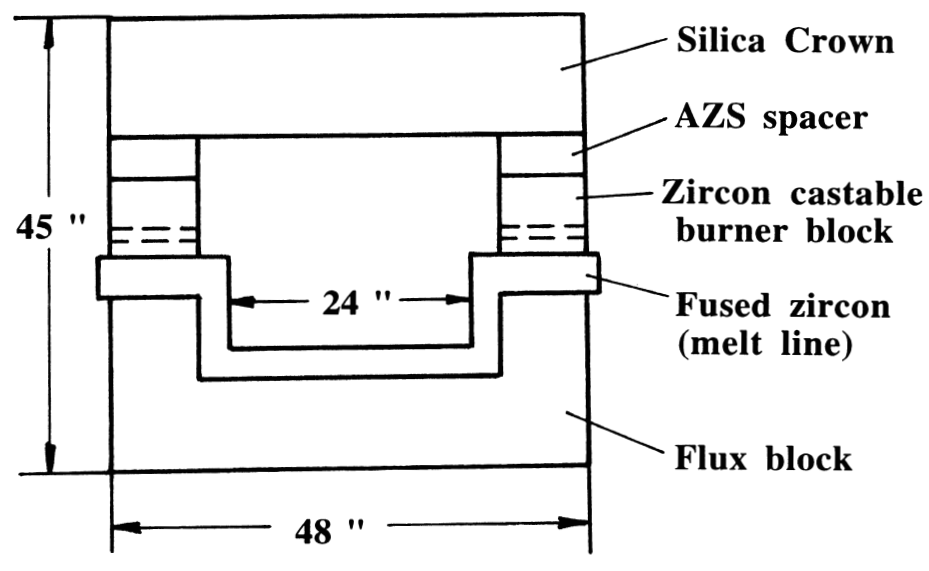

Figure 1: Front view of the proposed laboratory oxy-fuel furnace. The internal depth of the fused zircon panel is 48 . liquid phase. The reaction product $\mathrm{Na}_{2} \mathrm{SiO}_{3}$ (liq) migrates, due to its low viscosity, from the reaction interface to the $\mathrm{SiO}_{2}$ matrix. Mullite refractories showed better resistance to $\mathrm{Na}_{2} \mathrm{O}$ attack, being attacked by vapors mainly in regions of the matrix which contains fine mullite grains.

Kotacska [36] developed a gas/oxy laboratory furnace for simulating conditions thought to be the major causes for accelerated corrosion of refractory superstructures in oxy-fired furnaces. The variables included oxygen atmosphere, concentration of volatile species, raw material/cutlet ratio, and temperature as these were thought to be dominant factors in superstructure corrosion.

Refractory composition and furnace design and construction were also considered important parameters. The furnace included the potential to interchange oxy-fuel burners with conventional burners, incorporated methods of dynamically charging the furnace, and allowed superstructure temperature control from 1000 to $1700^{\circ} \mathrm{C}$.

The final design uses actual crown brick wedges rather than specimens of refractory bricks or blocks. The concept also included the potential to utilize a portable crown. This furnace can simulate both air and oxy firing conditions, allowing control of variables such as temperature, concentration of volatile, starting material types, design, and construction.

Gupta [37] summarized ongoing investigations at Carborundum concerning corrosion of refractories. The glass compositions selected for the study corresponded to container, fiber, and TV glasses. A range of fused-cast and bonded refractories were subjected to vapor phase corrosion under oxy-fuel and air-fuel atmospheres.

Microanalysis was used to determine diffusion depths and corrosion mechanisms. The results were compared with data from thermodynamic modeling and phase diagrams. It was concluded that (1) $\mathrm{NaOH}$ is the predominant vapor species for both air-fuel and oxy-fuel; (2) the oxy-fuel $\mathrm{NaOH}$ concentration is approximately double of the corresponding air-fuel $\mathrm{NaOH}$ concentration; (3) the $\mathrm{NaOH}$ concentration increases with increasing temperature; (4) since creation of $\mathrm{H}_{2} \mathrm{O}$ during both air-fuel combustion leads to $\mathrm{NaOH}$ formation, any testing procedure that does not control $\mathrm{H}_{2} \mathrm{O}$ concentration in the environment will not relate to testing under true combustion conditions (i.e., accelerated vapor corrosion testing of refractories can lead to incorrect material selection); and (5) thermodynamically, alumina refractories are expected to outperform silica and mullite in a corrosive flint container oxy-fuel furnace.

\section{DISCUSSION}

Any refractories corrosion testing-program must yield good reproducibility. Some aspects to be considered when comparing different corrosion rates in actual melters are: (1) the thickness of refractories, since thinner refractories will be cooled more effectively, (2) the operating temperatures in the furnace, which may be lower than expected, and (3) any decrease in the amounts of glass being melted. Laboratory corrosion testing usually compares corrosion characteristics, measuring chemical compatibility between glass and refractory. However, they may not directly measure corrosion circumstances, for instance, the ASTM tests do not evaluate the effects of thermal conductivity, artificial cooling, insulation, batch material attack, and erosion. Glass-refractory corrosion obtained from furnaces is necessary to assign significance 
to the laboratory data, because such corrosion reflects all the aspects of the melting process. The most reliable information about a physical process is, of course, given by actual measurement. A fullscale test is extremely impracticable and impossible. Theoretical calculations (given that all processes have adequate mathematical description) would support any experimental work. The benefits of modeling include the low cost duration of analysis and the ability of simulate realistic as well as ideal conditions. Prior to expansive engineering analysis, preliminary estimates of real situations can be performed. Turner [38] presented a straightforward analysis based on thermodynamics which could be applied effectively in some cases.

Some issues that need to be established prior to a simulation include: (1) chemical kinetics on batch melting and reactions in the glass, chemical equilibrium, solubility data, and chemical kinetics during refining; (2) the thermophysical properties of glass compositions; (3) coupling of combustion-heat transfer models to glass bath models; (4) data for predicting melting and refining kinetics of silica dissolution, bubble dynamics, and glass quality; (5) analysis and synthesis between numerical predictions and operating data; (6) complete understanding of physico-chemical processes to improve models and provide more accurate predictions.

Little has been published on the thermodynamic aspects of the corrosion reaction of ceramic oxides by silicate melts. This is an area that can be expanded. Other important areas of research encompass: (1) development of new refractories or compositions with improved properties (i.e., [39]); and (2) understanding of the glass melting process, by developing relations expressing the influence of temperature, glass composition, batch granulometry, and glass convection, in order to demonstrate the significance of the dissolution phenomena in glass melting [i.e.,40].

\section{CONCLUSIONS}

The chemical reactions at the surfaces of refractories may take place between molten slag, fluxing agents, and volatile components. Regarding refractories for glass melters, the points of innovation are expected to be [41]: higher corrosion resistance to molten glass; no defects in glass environmental compatibility; reliable properties; and improved methodology to identify origins of defects.

Three different tests are required to simulate the critical corrosion processes which occur: flux-line corrosion, throat corrosion, and crown corrosion. The following procedure is proposed for screening and/or characterizing new and used refractories.

1. Use ASTM C-621 for intended refractory compositions and/or intended glass melts. This standard has been used with frequency and the set-up is relatively simple. Use optical and scanning microscope to aid in interpreting results.

2. Use Cup-slag type test with an additional sample rotating at different speeds (i.e., rotating cylinder test). This will provide dynamical corrosion data.

3. Review literature on thermodynamical considerations of the intended systems (refractory plus slags, vapors, etc.). Compare this information to actual experimental data.

4. Monitor experiments in plant and conduct extensive postmortem characterization [i.e.,35,42]. This is an important issue, where specimens can be placed or taken from actual glass tanks.
By combining test results from as industrial setting and controlled laboratory tests [e.g., 43] a more reliable understanding of the corrosion process will be achieved .

Usual analysis techniques (optical microscopy, SEM with microprobe analysis, XRD, XRF, and thermal analysis) should be coupled with other technique such as: cathodoluminescent $[44,45]$; use of water-cooled periscopes and video photography $[46,47]$; microwave devices to measure wall thickness [48]; and on-line monitoring of glass tank corrosion by ultrasonic and electromagnetic methods [49].

A pilot-size oxy-fuel furnace is being built for simulating corrosion attack under different conditions [50]. Fig. 1 presents a schematic view of the furnace, which will allow simulation of oxyfuel corrosion tests. It will employ on-line monitoring of glasstank corrosion by ultrasonic and electromagnetic methods.

\section{REFERENCES}

[1] G.L. Ridderbush, Ceram. Ind. (March 1991) 48.

[2] L.M. Sheppard, Ceram. Ind. (Dec. 1996) 37.

[3] R. Bruckner, Glastechn. Ber. 53, 4 (1980) 77-88.

[4] A. R. Cooper, W.D. Kingery, J. Am. Ceram. Soc. 47, 1 (1964) 37.

[5] M. Dunkl, Glasteechn. Ber. 67,12 (1994) 325.

[6] J.R. Hutchins, Glass Technol. 7 (1966) 42.

[7] B.N. Samaddar, W. D. Kingery, A .R. Cooper, J.Am.Ceram. Soc. 47, 5(1964) 249.

[8] S. E. Feldman, W.K. Lu, P.S. Nicholson, A. E. Hamielec, Met. Trans. 5 (1974) 249.

[9] N. McCallum, L.R. Barrett, Trans. Brit. Ceram. Soc. 51 (1952) 523.

[10] L. Reed, L.R. Barret, Trans. Brit. Ceram. Soc. 63 (1964) 509.

[11] F.G. Baucke, G. Roth, Glastechn. Ber. 61, 5 (1988) 109.

[12] L. Leger, M. Boffe, E. Plumat, Glass Technol. 1, 4 (1960) 174.

[13] D. Barham, L.R. Barret, Trans. Brit. Ceram. Soc. 67 (1980) 49.

[14] M. Sadfar, D. Barham, L.R. barret, Thermal Analysis 3 (1974) 995.

[15] C. Wagner, J. Phys. Colloid Chem . 53 (1949) 1030.

[16] ASTM C-621: Standard Test Method for isothermal corrosion of refractories to molten glass.

[17] ASTM C - 622: Standard Test Method for corrosion resistance of refractories to molten glass using the basin furnace.

[18] ASTM C-768: Standard Practice for drip slag testing refractory brick at high temperature.

[19] Harbison-Walker Modern Refractory Practice, 5 th edition, HW Refractories, Compass Marketing Services Inc., Pittsburgh, 1992. [20] M. Dunkl, R. Bruckner, Interceram, special issue, (1986) 57.

[21] M. Dunkl, R. Bruckner, Glastechn. Ber. 60, 8 (1987) 261.

[22] M. Dunkl, R. Brucckner, Glastechn. Ber. 62, 1 (1989) 10.

[23] R. N. McNally, G.H. Beall, J. Mater. Sci. 14 (1979) 2596.

[24] V.K. Pavlovskii, Yu. S. Sobolev, Steklo i Keramika 6 (1991) 7.

[25] D.L. Orlov, V.V. Kiryukhin, O . N. Popov, V. A.Sokolov, Steklo i Keramika 4 (1986) 12.

[26] E. Thomas, D. Patel, Interceram, special issue (1986) 50.

[27] G. Aspholm, T. M. Wehrenberg, Ceram. Eng. Sci. Proc. 11, 1-2 (1990) 151.

[28] T.M. Wehrenberg, C.N. McGarry, Ceram. Eng. Sci. Proc. 9, 1-2 (1988) 82 .

[29] E. A. Thomas, J. Can. Ceram. Soc. 44 (1975) 37.

[30] ASTM C-987: Vapor attack on refractories for furnace 
superstructures.

[31] T.S. Busby, MRS Bull., (Nov. 1989) 45.

[32] B. H. Bieler, Am. Ceram. Soc. Bull. 61, 7 (1982) 746.

[33] O. N. Popov, V.P. Frolova, Ogneupory 11 (1985) 50.

[34] G. Routschka, Interceram, special issue (1988) 54.

[35] J. Boillet, W. Kobayashi, W. J. Snyder, C.A Paskocimas, E. R. Leite, E. Longo, J. A. Varela, Ceram. Eng. Sci. Proc. 17, 2 (1996) 180. [36] L. H. Kotacska, J. T. Brown, T. J. Cooper, Ceram. Eng. Sci. Proc. 16, 2 (1995) 150.

[37] A. Gupta, S. M. Winder, Ceram. Eng. Sci. Proc. 17, 2 (1996) 112.

[38] W. H. Turner, Ceram. Eng. Sci. Proc. 8, 3-4 (1987) 142.

[39] S. Lutskanov, Glass Technol. 37, 4 (1996) 112.

[40] L. Nemec, Ceramics-Silikaty 39, 3 (1995) 81.

[41] K. Kondoh, K. Sakai, T. Ishino, H. Abe. UNITECR'95, Vol. 1 (1995) 67.
[42] D. Shamp, Am. Ceram. Soc. Bull. 76, 3 (1997) 64.

[43] D. P. Butt, J.J. Mecholsky, Report No GRI-88/0134, Oct. 1988. [44] R.E. Moore, M. Karakus, Proc. Int. Ceram. Conf. Austeceram'94, Sidney, Australia, Vol. 1,2 (1994) 925.

[45] M. Karakus, R.E. Moore, Corrosion of Materials by Molten Glass. Ceram. Trans. Vol. 78, p. 179, The American Ceramic Society, 1996.

[46] G. Neff, J. Nabors, Ceram. Eng. Sci. Proc. 11, 1-2 (1990) 18. [47] J. F. Wosinski, J. T. Brown, Ceram. Eng. Sci. Proc. 14, 3-4 (1993) 223.

[48] T. S. Busby, Glass Technol. 28, 1 (1987) 30.

[49] T.J. Herrick, Proc. Oxy-Fuel Issues for Glassmaking in the 90's. DOE/Conf-970292, U.S. Department of Energy, p. 275, Feb. 1997. [50] R.E. Moore, Proc. Oxy-Fuel Issues for Glassmaking in the 90's. DOE/Conf-970292, U.S. Department of Energy, p. 263, Feb. 1997. (Rec. 01/12/97, Ac. 02/01/98). 